\title{
PENGEMBANGAN MODEL PEMBELAJARAN SAINTIFIK PADA MATA PELAJARAN AKUNTANSI PERUSAHAAN DAGANG UNTUK SISWA KELAS XI JURUSAN AKUNTANSI
}

\author{
Oleh: \\ Mirza Rahmadany \\ Jurusan Akuntansi Universitas Negeri Malang \\ Bety Nur Achadivah \\ Jurusan Akuntansi Universitas Negeri Malang
}

\begin{abstract}
Abstrak
Tujuan dari penelitian ini adalah untuk mengembangkan model pembelajaran Problem Based Learning dan Project Based Learning dengan menggunakan pendekatan pembelajaran saintifik dalam mata pelajaran akuntansi perusahaan dagang kelas XI Akuntansi SMK Negeri 1 Malang. Jenis penelitian yang digunakan adalah penelitian pengembangan dengan menggunakan model penembangan Borg and Gall (1983) yang telah dimodifikasi sesuai kebutuhan penelitian. Subjek coba penelitian ini adalah guru mata pelajaran akuntansi perusahaan dagang serta siswa kelas XI AK 3 dan XI AK 4 yang masing-masing berjumlah 36 dan 31 siswa. Data dianalisis dengan menggunakan teknik analisis isi dan deskriptif persentase. Hasil validasi ahli pembelajaran diperoleh nilai sebesar $84,38 \%$, $75 \%$ dari ahli materi, $77,26 \%$ dari ahli pengembangan bahan ajar, serta dari pengguna yaitu guru $75 \%$ dan siswa sebesar 82,29\%. Rata-rata persentase keseluruhan sebesar 79,79\% untuk model pembelajaran, $75 \%$ untuk materi pembelajaran yang terdapat dalam buku guru dan siswa, serta $77,26 \%$ untuk buku siswa sehingga dapat disimpulkan bahwa model pembelajaran yang terdiri dari buku guru dan siswa yang dikembangkan layak serta dapat digunakan dalam proses pembelajaran.Saran pengembangan produk lebih lanjut: (1) Model pembelajaran ini masih digunakan hanya di satu mata pelajaran dan satu sekolah. Pengembangan selanjutnya dapat menggunakan materi atau pelajaran lain dan sekolah lainnya. (2) Penelitian selanjutnya diharapkan dapat mengembangkan model pembelajaran dengan konsep yang lain, (3) Penelitian selanjutnya diharapkan dapat menguji efektifitas model pembelajaran saintifik dan membandingkan model pembelajaran ini dengan model pembelajaran lainnya.
\end{abstract}

Kata Kunci: Model Pembelajaran, Saintifik, Akuntansi, Problem Based Learning, Project Based Learning

\begin{abstract}
The goal of this research is to develop learning model namely problem-based learning and projectbased learning using scientific learning model on company trading accounting for grade XI of State Vocational School 1 Malang. This research uses Research and Development (R\&D) model developed by Borg and Gall (1983) which is modified to match the research's needs. Participants of the research are the teacher of company trading accounting lesson, and 36 students of grade XI AK3 and 31 students of grade XI AK 4. Data analysis uses content analysis and presentage description. The result of learning expert is $84,38 \%$, 75\% of expert of materials, 77,26\% of expert of material development,75\% of teacher, and 82,29\% of students. The average of the overall learning model yields 79,79\%, 75\% for learning materials of teacher book and student, and 77,26\% for student book. On the basis of these results, they show that the learning model reflected in the developed book (teacher and student books) are good and eligible to use in learning process. The suggestions made for further research development are 1) the learning model is still solely used in one lesson only, and in this school only. It emphasizes the need of developing materials using the model for other lessons and other schools. 2) further research is expected to aim at developing learning model using another
\end{abstract}


concept, 3) further research is expected to test the effectiveness of scientific learning model and to compare this learning method with other learning models.

Key words: Leaning model, Scientific, Accounting, Problem Based Learning, Project Based Learning

\section{PENDAHULUAN}

Pendidikan merupakan salah satu tolak ukur kemajuan suatu bangsa. Seiring pesatnya kemajuan ilmu pengetahuan, teknologi, seni, budaya serta persaingan pada era global menuntut adanya perbaikan mutu pendidikan yang dilakukan sesuai perkembangan zaman untuk menghasilkan lulusan yang berkualitas. Pemerintah telah berupaya meningkatkan mutu pendidikan nasional dengan melakukan pengembangan kurikulum 2013 namun dalam implementasinya masih memerlukan penyempurnaan. Salah satunya adalah terkait upaya pendidik dalam mengatur dan memberdayakan berbagai variabel pembelajaran seperti lingkungan belajar yang terdiri dari interaksi pendidik dengan peserta didik, antar peserta didik, alat, bahan ajar, dan sumber belajar guna mendukung keberhasilan peserta didik mencapai tujuan pembelajaran. Hal tersebut sejalan dengan pendapat (Hosnan, 2014:299) yang menyatakan bahwa semua variabel tersebut saling terkait dalam mendukung tercapainya tujuan pendidikan yang ditentukan. Perancangan pembelajaran hendaknya dilakukan oleh pendidik sebelum melakukan kegiatan pembelajaran dengan cara menentukan metode, strategi, dan pendekatan dalam mendesain model pembelajaran yang tepat disesuaikan dengan tujuan pembelajaran, materi yang akan disampaikan, jumlah peserta didik, dan perkembangan peserta didik. Guru perlu menguasai dan dapat menerapkan berbagai keterampilan mengajar agar dapat mencapai tujuan pembelajaran yang beraneka ragam, karena setiap model memerlukan sistem pengelolaan dan lingkungan belajar yang berbeda (Trianto, 2012:55).

Permasalahan yang timbul dari proses pembelajaran di kelas diantaranya pembelajaran yang masih berpusat pada guru dan penerapan model pembelajaran yang belum efektif. Pembelajaran yang masih berpusat pada guru mengakibatkan peserta didik menjadi pasif dan jenuh selama mengikuti pembelajaran. Kurang matangnya perencanaan guru dalam mendesain pembelajaran seperti tidak tersedianya bahan ajar yang mendukung pembelajaran menyebabkan peserta didik kesulitan dalam memahami materi pelajaran sehingga berdampak pada hasil belajar yang kurang maksimal.

Proses pembelajaran pada kurikulum 2013 diarahkan untuk berpusat pada siswa. Pembelajaran harus mengarahkan siswa belajar secara aktif dan mandiri bukan hanya menerima pengetahuan yang diberikan oleh guru saja. Siswa yang belajar dengan aktif dan mandiri akan mencari tahu, mengolah, mengonstruksi, dan memahami dengan pengalamannya sendiri sehingga pengetahuan yang diperolehnya akan bermakna dan tahan lama. Peserta didik perlu didorong untuk bekerja memecahkan masalah, menemukan segala sesuatu untuk dirinya, dan berupaya keras mewujudkan ide-idenya supaya dapat benar-benar memahami dan dapat menerapkan pengetahuannya (Permendikbud Nomor 81A Tahun 2013).

Mengacu pada permasalahan di atas, sebagai salah satu sekolah yang ditunjuk menjadi sasaran uji coba implementasi kurikulum 2013 maka diperlukan pengelolaan pembelajaran yang sesuai tujuan kurikulum sehingga dapat mengakomodasi siswa belajar secara aktif dan berpikir kritis. Proses pembelajaran dalam implementasi kurikulum 2013 menerapkan pembelajaran dengan menggunakan pendekatan saintifik (scientific approach). Pendekatan saintifik 
merupakan suatu pendekatan pembelajaran yang mengarahkan peserta didik secara aktif mengkonstruk konsep, hukum atau prinsip melalui tahapan ilmiah yang dikemas dalam kegiatan inti pembelajaran yang mencakup kegiatan mengamati (observing), menanya (questioning), mencoba/mengumpulkan data (experimenting), menalar/mengasosiasi (associating), dan mengkomunikasikan (communicating) (Hosnan, 2014:34). Beberapa model, strategi, atau metode pembelajaran dapat diterapkan guru dengan mengintegrasikan elemen-elemen pendekatan saintifik dalam pembelajaran. Model yang sesuai dengan pendekatan pembelajaran saintifik antara lain pembelajaran berbasis masalah (problem based learning) dan pembelajaran berbasis proyek (project based learning) (Sani, 2014:76). Seperti yang dikemukakan Sani (2014:127), problem based learning didefinisikan sebagai proses pembelajaran yang membuat siswa belajar melalui upaya penyelesaian permasalahan dunia nyata (real world problem). Sementara itu, project based learning didefinisikan (Sani, 2014:172) sebagai pembelajaran yang melibatkan siswa dalam merancang, membuat, dan menampilkan produk untuk mengatasi atau menyelesaikan permasalahan dunia nyata. Berdasarkan dua definisi tersebut dapat dinyatakan persamaan problem based learning dan project based learning yaitu terkait bagaimana mempelajari konsep berdasarkan permasalahan dan menerapkan kemampuan menyelesaikan masalah yang terjadi pada dunia nyata. Sedangkan perbedaan diantara keduanya adalah adanya produk yang harus dibuat dan ditampilkan siswa dalam project based learning (Sani, 2014:172). Penggunaan dua model tersebut secara bergantian dalam pembelajaran sesuai konteks materi yang dipelajari dapat menciptakan lingkungan pembelajaran bermakna yang bertujuan bukan hanya menyentuh aspek pengetahuan saja namun juga dapat menyentuh aspek sikap, dan keterampilan karena siswa dilatih bekerja sama, berkomunikasi, menyelesaikan permasalahan, dan membuat keputusan.

Pada penelitian ini, dikembangkan pembelajaran model problem based learning dan project based learning menggunakan pendekatan pembelajaran saintifik. Uji coba akan dilakukan pada siswa kelas XI jurusan akuntansi SMK Negeri 1 Malang. Pemilihan subjek uji coba tersebut dikarenakan lulusan SMK dituntut untuk bukan hanya memahami konsep namun juga praktek sehingga siswa SMK perlu dilatih untuk menyelesaikan permasalahan dunia nyata yang ada, membuat produk, dan menampilkannya. Materi yang digunakan seputar akuntansi perusahaan dagang untuk siswa kelas XI SMK sesuai silabus kurikulum 2013. Materi ini dianggap relevan jika diterapkan dengan menggunakan pembelajaran berbasis masalah dan proyek.

Model pembelajaran adalah suatu pola yang menggambarkan urutan kegiatan pembelajaran dan penciptaan lingkungan belajar dari awal hingga akhir pelajaran yang disajikan oleh guru termasuk di dalamnya penentuan pendekatan, strategi, metode yang sesuai dengan materi yang akan disampaikan, tujuan pembelajaran, dan tingkat kemampuan peserta didik sehingga memungkinkan siswa untuk mencapai tujuan belajar tertentu.

Pada dasarnya, dalam pengembangan model pembelajaran terdapat unsur dasar yang terlibat erat. Joyce \& Weil (1980:16) mengungkapkan lima unsur dasar dalam model pembelajaran yaitu 1) syntax, 2) social system, 3) principles of reaction, 4) support system, 5) instructional dan nurturant effect. Oleh karena itu, penilaian (evaluasi) model pembelajaran dikatakan telah baik apabila telah memenuhi lima unsur tersebut.Penilaian terhadap hasil pengembangan model pembelajaran ini juga mencakup penilaian materi dan kualitas bahan ajar berupa buku petunjuk guru dan buku siswa yang akan digunakan dalam implementasi model pembelajaran Problem 
Based Learning dan Project Based Learning.

Problem Based Learning merupakan suatu model pembelajaran yang mengarahkan peserta didik untuk berpikir kritis dalam menyelesaikan permasalahan dunia nyata untuk memperoleh konsep dari materi yang dipelajari dengan peran guru yang bertindak sebagai fasilitator di dalam pembelajaran.Sedangkan

Project-based learning merupakan model pembelajaran yang mengarahkan siswa pada pengerjaan proyek untuk menyelesaikan permasalahan yang terjadi pada dunia nyata.

Kedua model pembelajaran tersebut memiliki tahapan pembelajaran yang berbeda. Problem based learning menurut Ibrahim, dkk (2000) dalam Trianto (2010:98) memiliki lima tahapan yaitu 1) Orientasi siswa pada masalah, 2) Mengorganisasi siswa untuk belajar, 3) Membimbing penyelidikan individual maupun kelompok, 4) Mengembangkan dan menyajikan hasil karya, 5) Menganalisis dan mengevaluasi proses pemecahan masalah. Sedangkan Project Based Learning menurut The George Lucas Educational Foundation (2005) dalam Nurohman (2007:10) memiliki enam tahapan diantaranya 1) Penentuan Pertanyaan Mendasar, 2) Mendesain Perencanaan Proyek, 3) Menyusun Jadwal, 4) Memonitor Siswa dan Kemajuan Proyek, 5) Menilai Hasil, 6) Mengevaluasi Pengalaman. Penilaian pada Problem Based Learning dan Project Based Learning menggamit tiga aspek yaitu aspek kognitif, afektif, dan psikomotorik.

\section{METODE PENELITIAN}

Penelitian dan pengembangan ini bertujuan menghasilkan suatu produk berupamodel pembelajaran saintifik yaitu model pembelajaran Problem Based Learning dan Project Based Learning yang dikembangkan dengan menggunakan pendekatan pembelajaran saintifik. Model pembelajaran ini dapat digunakan dalam proses pembelajaran sesuai kurikulum 2013 untuk mata pelajaran akuntansi perusahaan dagang kelas XI pada materi akuntansi perusahaan dagang. Sesuai dengan tujuan tersebut, maka penelitian ini menggunakan metode Penelitian dan Pengembangan (Research and Development/R\&D) yang dimodifikasi sesuai kebutuhan penelitian dari model Borg and Gall (1983). Langkahlangkah yang dilakukan yaitu (1) analisis kebutuhan, (2) pengembangan produk, (3) uji validitas produk, (4) revisi produk ke-1, (5) uji pengguna terbatas, (6) revisi produk ke-2, (7) produk akhir.

Analisis kebutuhan dilakukan berdasarkan kebutuhan model pembelajaran dengan menggunakan pendekatan saintifik sesuai kurikulum 2013. Pengembangan produk dilakukan melalui tigatahapan, yaitu persiapan, penyusunan produk dan penyelesaian produk. Uji validitas produk dilakukan setelah produk dikembangkan untuk mengetahui kelayakan produk sebelum digunakan oleh pengguna. Uji validitas produk dilakukan oleh ahli pembelajaran, ahli materi, dan ahli pengembangan bahan ajar. Pengguna terbatas dalam penelitian ini adalah guru pengampu mata pelajaran akuntansi perusahaan dagang serta siswa kelas XI AK3 dan XI AK 4 SMK Negeri 1 Malang yang masing-masing kelas berjumlah 36 dan 31siswa.

Data yang diperoleh berupa data kuantitatif dan data kualitatif. Untuk data kualitatif dilakukan analisa isi dari komentar dan saran dari validator. Sedangkan untuk data kuantitatif dianalisis dengan menggunakan teknik analisis deskriptif persentase. Instrumen yang digunakan dalam pengumpulan data penelitian dan pengembangan ini berupa angket dengan skala likert 1,2,3,4. Angket yang digunakan yaitu angket validasi untuk ahli pembelajaran, materi, bahan ajar, tanggapan guru dan siswa terhadap model pembelajaran Problem Based Learning dan Project Based Learning dengan menggunakan pendekatan saintifik.

Teknik analisis data yang digunakan adalah: 
Rumus untuk penilaian per item:

$P_{i}=\frac{x_{i}}{y_{i}} \times 100 \% \quad$ (Sudjana, 1990:45)

Rumus untuk penilaian keseluruhan item:

$P=\frac{\sum_{i}^{n} l X i}{\sum_{i}^{n} l Y i}$

(Sudjana, 1990:45)

Keterangan:

$P_{i} \quad:$ Persentase penilaian item/kriteria ke-i

P : Persentase penilaian keseluruhan

$x_{i} \quad$ : Skor untuk item/kriteria ke-i

$y_{i} \quad:$ Skor maksimal untuk item/kriteria

ke-i

$\sum_{i}^{n} l X i \quad$ : Jumlah skor untuk item/kriteria ke-i

$\sum_{i}^{n} l Y i$ : Jumlah skor maksimal untuk item/kriteria ke-i

$\mathrm{N}$ : Banyak item/kriteria yang dinilai dalam validasi

$l \quad: 1,2,3,4,5, \mathrm{n}$

$100 \%$ : Konstanta

Tingkat kelayakan produk hasil penelitian dan pengembangan menggunakan persentase skor. Semakin baik persentase skor hasil analisis data maka semakin baik tingkat kelayakan produk hasil penelitian dan pengembagan. Kriteria tingkat kelayakan analisis persentase poduk hasil pengembangan disajikan dalam Tabel 1 .

Tabel 1 Kriteria Kelayakan Model Pembelajaran Saintifik

\begin{tabular}{|l|l|}
\hline $\begin{array}{l}\text { Persentase } \\
\text { Penilaian }\end{array}$ & Interpretasi \\
\hline $81 \%-100 \%$ & Sangat Layak \\
$61 \%-80 \%$ & Layak \\
$41 \%-60 \%$ & Cukup Layak \\
$21 \%-40 \%$ & Kurang Layak \\
$0 \%-20 \%$ & Tidak Layak \\
\hline
\end{tabular}

(Sumber: Arikunto, 2010:44)

Setelah kriteria kelayakan produk pengembangan diketahui, maka harus diputuskan apakah produk tersebut perlu direvisi atau tidak. Saran dari validator, guru, dan siswa menentukan keputusan dilakukannya revisi.

\section{HASIL PENELITIAN DAN PEMBAHASAN \\ Produk Hasil Pengembangan}

Produk yang telah dikembangkan ini berupa pembelajaran saintifik yang mengintegrasikan langkah-langkah model pembelajaran Problem Based Learning dan Project Based Learning yang diwujudkan dalam bentuk buku guru dan buku siswa sesuai kurikulum 2013. Produk hasil pengembangan disajikan pada Tabel 2 berikut ini:

Tabel 2 Cuplikan Pengembangan Produk Buku Siswa dan Buku Guru

\begin{tabular}{|c|c|c|}
\hline No. & Produk & Keterangan \\
\hline 1. & $\begin{array}{l}\text { Buku } \\
\text { Siswa }\end{array}$ & $\begin{array}{l}\text { Cover, Kata Pengantar, } \\
\text { Daftar Isi, Petunjuk } \\
\text { Penggunaan Buku Siswa, } \\
\text { Model Penyajian, Peta } \\
\text { Konsep, Penyampaian } \\
\text { Materi ((1) penyediaan } \\
\text { informasi persediaan } \\
\text { barang dagangan, (2) } \\
\text { pencatatan dengan metode } \\
\text { periodik, (3) pencatatan } \\
\text { dengan metode perpetual, } \\
\text { (4) penentuan harga pokok } \\
\text { penjualan, (5) penentuan } \\
\text { harga pokok penjualan } \\
\text { dengan metode periodik, } \\
\text { (6) penentuan harga pokok } \\
\text { penjualan dengan metode } \\
\text { perpetual), Latihan dan } \\
\text { Penugasan, } \\
\text { Kemampuan, Evaluasi, } \\
\text { Penilaian, Glosarium, } \\
\text { Daftar Rujukan, Indeks, } \\
\text { Biodata Penulis. }\end{array}$ \\
\hline 2. & $\begin{array}{l}\text { Buku } \\
\text { Guru }\end{array}$ & $\begin{array}{l}\text { Cover, Kata } \\
\text { Daftar Isi, } \\
\text { Kompetensi, } \\
\text { Belakangantar, } \\
\text { Model Pengembangan } \\
\text { Skenario Pembelajaran, } \\
\text { Kunci Jawaban Buku } \\
\text { Siswa, Contoh RPP, } \\
\text { Format Penilaian, Daftar } \\
\text { Rujukan, Biodata Penulis. }\end{array}$ \\
\hline
\end{tabular}




\section{Analisis Data}

Berdasarkan validasi oleh tiga validator dan uji coba pengguna terbatas diketahui bahwa seluruh produk hasil pengembangan dinyatakan layak tetapi masih perlu dilakukan revisi pada beberapa bagian. Berdasarkan validasi ahli pembelajaran diperoleh rata-rata persentase $84,38 \%$, serta rata-rata validasi uji coba produk pengguna terbatas guru dan siswa kelas Project Based Learning dan Problem Based Learning memperoleh persentase rata-rata $78,64 \%$. Berdasarkan analisis keseluruhan validasi model pembelajaran diperoleh rata-rata persentase sebesar 79,79\%. Sedangkan untuk ahli materi diperoleh persentase $75 \%$. Selanjutnya, untuk ahli pengembangan bahan ajar diperoleh persentase $77,26 \%$.

\section{Revisi Produk}

Revisi bertujuan memberikan masukan agar model pembelajaran yang dikembangkan menjadi lebih baik. Revisi dilakukan berdasarkan kritik, saran, dan pendapat para ahli dan pengguna terbatas. Berikut adalah bagian yang mengalami revisi disajikan dalam Tabel 3.

Tabel 3 Revisi Produk Pengembangan

\begin{tabular}{|c|c|}
\hline Validator & Keterangan \\
\hline $\begin{array}{l}\text { Ahli } \\
\text { Pembelajaran }\end{array}$ & $\begin{array}{lr}\text { 1. Pada Buku } & \text { Guru } \\
\text { indikator pencapaian } \\
\text { kompetensi } & \text { pada } \\
\text { masing-masing } & \\
\text { kompetensi } & \text { dasar } \\
\text { belum menunjukkan } \\
\text { pencapaian } r \text { tersebut } \\
\text { sehingga pada } & \text { seluruh } \\
\text { Kompetensi r Dasar } \\
\text { dilakukan revisi pada } \\
\text { indikator pencapaian } \\
\text { kompetensi r yang } \\
\text { tercermin ralam } \\
\text { skenario pembelajaran } \\
\text { (tujuan pembelajaran) } \\
\text { atau RPP pada } \\
\text { indikator pencapaian } \\
\text { kompetensi. }\end{array}$ \\
\hline
\end{tabular}

\begin{tabular}{|c|c|}
\hline & 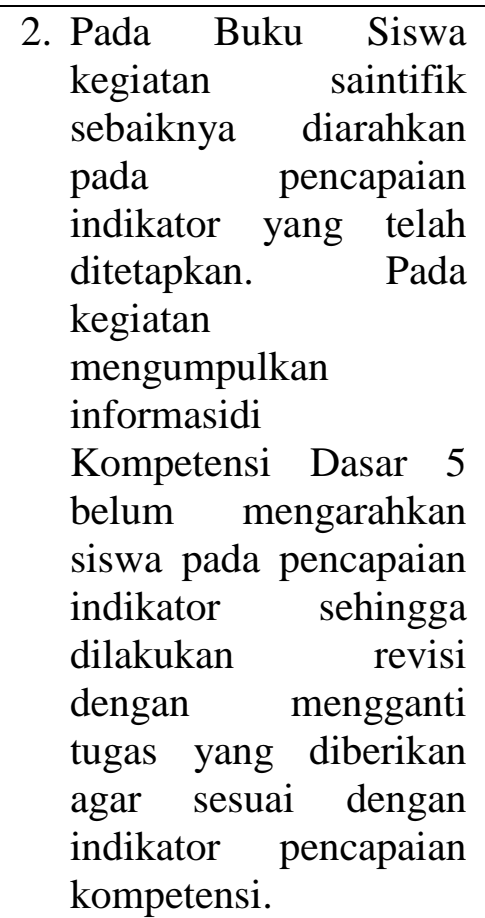 \\
\hline Ahli Materi & 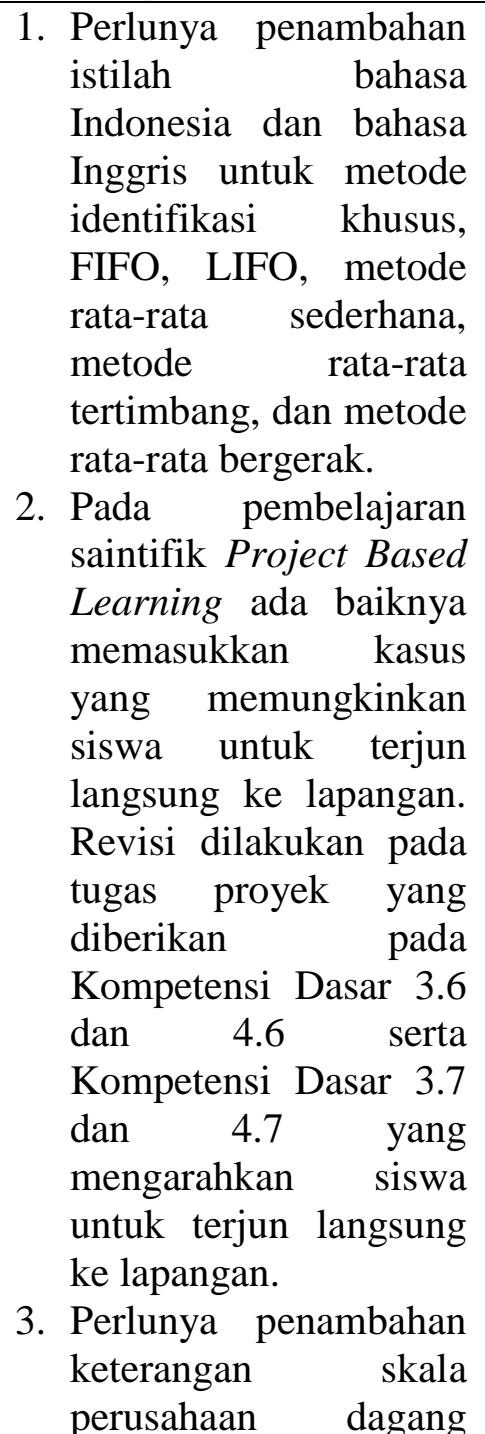 \\
\hline
\end{tabular}




\begin{tabular}{|c|c|}
\hline & $\begin{array}{l}\text { yang sederhana sebagai } \\
\text { tanda cakupan } \\
\text { pembahasan } \\
\text { keseluruhan isi buku } \\
\text { agar terhindar dari } \\
\text { pembahasan yang lebih } \\
\text { rumit. } \\
\text { 4. Penyusunan materi } \\
\text { pada buku siswa perlu } \\
\text { dipadadatkan tepatnya } \\
\text { pada pembahasan } \\
\text { sistem pencatatan } \\
\text { persediaan periodik } \\
\text { dan perpetual yang } \\
\text { semula terpisah pada } \\
\text { poin D dan F direvisi } \\
\text { menjadi poin D saja. }\end{array}$ \\
\hline $\begin{array}{l}\text { Ahli } \\
\text { Pengembangan } \\
\text { Bahan Ajar }\end{array}$ & 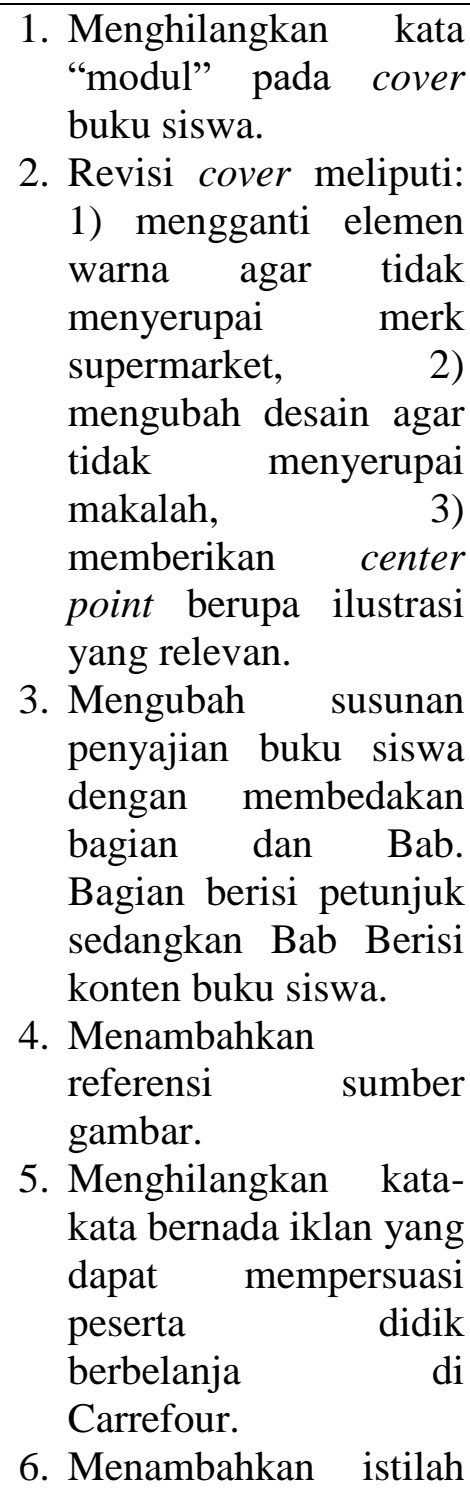 \\
\hline
\end{tabular}

\begin{tabular}{|l|l|}
\hline & \multicolumn{1}{|c|}{ dalam glosarium yang } \\
& sebelum revisi hanya \\
& 10 menjadi 21 setelah \\
& revisi. \\
7. & Menambahkan indeks \\
pada buku siswa. \\
8. Menambahkan daftar \\
rujukan yang relevan.
\end{tabular}

\section{SIMPULAN DAN SARAN}

Produk yang telah dikembangkan ini berupa pembelajaran saintifik yang mengintegrasikan langkah-langkah model pembelajaran Problem Based Learning dan Project Based Learning yang diwujudkan dalam bentuk buku guru dan buku siswa sesuai kurikulum 2013. 
Keseluruhan produk hasil
pengembangan dinyatakan layak berdasarkan hasil validasi dan uji coba pengguna terbatas. Berdasarkan validasi oleh tiga validator dan uji coba pengguna terbatas diketahui bahwa seluruh produk hasil pengembangan dinyatakan layak tetapi masih perlu dilakukan revisi pada beberapa bagian. Berdasarkan validasi ahli pembelajaran diperoleh rata-rata persentase $84,38 \%$, serta rata-rata validasi uji coba produk pengguna terbatas guru dan siswa kelas Project Based Learning dan Problem Based Learning memperoleh persentase rata-rata $78,64 \%$. Berdasarkan analisis keseluruhan validasi model pembelajaran diperoleh rata-rata persentase sebesar $79,79 \%$. Sedangkan untuk ahli materi diperoleh persentase $75 \%$. Selanjutnya, untuk ahli pengembangan bahan ajar diperoleh persentase 77,26\%.

Karakteristik

produk

pengembangan adalah menggunakan model pembelajaran saintifik yaitu model pembelajaran yang menggunakan pendekatan saintifik yang dikembangkan dengan menggunakan model Problem Based Learning dan Project Based Learning. Pada model pembelajaran ini siswa dikelompokkan dalam tim-tim yang berbeda dan melakukan tugas pemecahan masalah serta tugas proyek. Spesifikasi model pembelajaran yang dikembangkan secara umum berdasarkan langkah-langkah/sintaks masing-masing model pembelajaran yang diintegrasikan dalam kegiatan pembelajaran saintifik yaitu mengamati, menanya, mengumpulkan informasi, mengasosiasi, dan mengkomunikasikan. Tahapan dan skenario model pembelajaran saintifik ini disusun dalam buku guru dan buku siswa.

Kelebihan Produk diantaranya: 1) model pembelajaran yang dikembangkan sesuai dengan pendekatan pembelajaran yang digunakan dalam kurikulum 2013 yaitu dengan menggunakan pendekatan saintifik, 2) Pengembangan ini menggunakan dua model pembelajaran yang diintegrasikan dalam pendekatan pembelajaran saintifik yaitu Problem Based Learning dan Project Based Learning, 3) Pengembangan model pembelajaran ini disertai dengan buku guru dan buku siswa dalam mengimplementasikan pembelajaran saintifik model Problem Based Learning dan Project Based Learning, 4) Pada buku guru terdapat Rencana Pelaksanaan Pembelajaran sesuai kurikulum 2013 yang di dalamnya memuat skenario pembelajaran saintifik model Problem Based Learning dan Project Based Learning serta penilaian yang digunakan selama proses pembelajaran berdasarkan peraturan terbaru yaitu Permendikbud Nomor 104 tahun 2014 yang meliputi ketentuan atas penilaian ranah sikap, pengetahuan, dan keterampilan, 5) Buku siswa berisi materi, latihan, tugas, evaluasi yang sesuai dengan kompetensi dasar yang hendak dicapai, 6) Buku guru berisi kunci jawaban atas tugas atau evaluasi yang ada pada buku siswa sehingga memudahkan guru dalam melakukan pembahasan materi. Disamping kelebihan produk yang telah diungkapkan di atas, terdapat pula kelemahan produk pengembangan berupa model pembelajaran saintifik, diantaranya: 1) Membutuhkan waktu dalam memahami langkah-langkah model pembelajaran saintifik ini karena penggunaannya perlu disesuaikan dengan materi yang diajarkan baik yang menggunakan Problem Based Learning atau Project Based Learning, 2) Penggunaan model pembelajaran yang terus-menerus dapat membuat siswa bosan.

Saran yang diajukan berdasarkan hasil penelitian dan pengembangan ini antara lain: (1) Guru memerlukan waktu untuk memahami langkah-langkah pembelajaran saintifik model Problem Based Learning dan Project Based Learning, (2) Sebelum model pembelajaran saintifik ini diterapkan, guru terlebih dahulu harus mempelajari model tersebut melalui skenario pembelajaran, penilaian, dalam buku guru, (3) Guru perlu mengadakan kuis sewaktu-waktu agar siswa tidak bosan dan selalu termotivasi 
untuk belajar, (4) Sebelum mengikuti pembelajaran saintifik ini, siswa diharapkan membaca petunjuk penggunaan buku siswa, (5) Guru mengarahkan siswa untuk mengerjakan tugas individu pada kompetensi dasar 3.10 dan 4.10 agar seluruh tujuan pembelajaran dapat tercapai, (6) Penggunaan model pembelajaran saintifik ini dapat diterapkan pada skala yang lebih luas misalnya dengan menerapkannya pada mata pelajaran yang lain atau pada sekolah lainnya, (7) Guru perlu menjelaskan tujuan pembelajaran, skenario, dan materi menggunakan langkah-langkah model pembelajaran saintifik Problem Based Learning dan Project Based Learning kemudian siswa diarahkan untuk mempelajari buku siswa. Setelah itu, siswa dipersilakan untuk bertanya tentang tahapan yang kurang dipahaminya, (8) Pengembangan model pembelajaran saintifik dalam bentuk buku guru dan buku siswa ini digunakan untuk mengefektifkan proses pembelajaran akuntansi. Oleh karena itu, penerapan model pembelajaran perlu memperhatikan karakteristik siswa, (9) Bagi penelitian selanjutnya dapat melengkapi materi akuntansi perusahaan dagang yang harus dipelajari oleh siswa kelas XI jurusan akuntansi tingkat SMK, mengembangkan materi akuntansi lain atau materi mata pelajaran lain dan di sekolah lainnya, (10) Penelitian selanjutnya diharapkan dapat merancang dan mengembangkan model pembelajaran saintifik dengan basis model pembelajaran lain pada materi akuntansi perusahaan dagang untuk siswa kelas XI tingkat SMK misalnya dengan menggunakan Inquiry atau Discovery Learning sehingga dapat melengkapi model pembelajaran saintifik sesuai kurikulum 2013, (11) Penelitian selanjutnya diharapkan dapat menguji efektifitas model pembelajaran saintifik ini. Selain itu, dapat pula membandingkan model pembelajaran ini dengan model pembelajaran lainnya.

\section{DAFTAR PUSTAKA}

Abidin, Yunus. 2014. Desain Sistem Pembelajaran dalam Konteks Kurikulum 2013. Bandung: PT Refika Aditama.

Alexon, dkk. 2010. Pengembangan Model Pembelajaran Terpadu Berbasis Budaya untuk Meningkatkan Apresiasi Siswa terhadap Budaya Lokal. Cakrawala Pendidikan,XXIX (No.2): hlm.189, (Online), (http://core.ac.uk/download/pdf/11 059875.pdf), diakses 10 Agustus 2015.

Arends, Richard I. 1997. Classroom Instruction and Management. New York : McGraw-Hill Companies.

Arends, Richard I. 2008. Belajar untuk Mengajar (Learning to Teach) 2 Edisi Ketujuh. Yogyakarta: Pustaka Belajar.

Arikunto, Suharsimi. 2010. Prosedur Penelitian: Suatu Pendekatan Praktik (Edisi Revisi). Jakarta: Rineka Cipta.

Badan Standar Nasional Pendidikan. 2007. Standar Penilaian Kelayakan Penulisan Buku Teks. (Online), (http://bsnp-indonesia.org), diakses tanggal 10 Juni 2015.

Borg, Walter R \& Gall, Meredith Damien. 1983. Educational Research: An Introduction. Michigan: Longman.

Budiningsih, C. Asri. 2004. Belajar dan Pembelajaran. Yogyakarta: PT Rineka Cipta.

Dwipantara, Titis. 2011. Upaya Peningkatan Kualitas Pembelajaran Akuntansi melalui Penerapan Model Pembelajaran Problem Based Learning pada Siswa Kelas XII IPS 2 MAN Ngrambe Ngawi Tahun Ajaran 2010/2011. Skripsi tidak diterbitkan. Surakarta. Universitas Sebelas Maret.

Hidayat, Arifudin. 2014. Penerapan Pendekatan Saintifik pada Mata 
Pelajaran Pendidikan Agama Islam untuk Peningkatan Prestasi Belajar Kelas IB SDN 1 Bantul Tahun Ajaran 2013-2014. Skripsi tidak diterbitkan. Yogyakarta: Universitas Islam Negeri Sunan Kalijaga.

Hitipeuw. Imanuel. 2009. Belajar dan Pembelajaran. Malang: Fakultas Ilmu Pendidikan Universitas Negeri Malang.

Hosnan, M. 2014. Pendekatan Saintifik dan Kontekstual dalam Pembelajaran Abad 21. Bogor: Penerbit Ghalia Indonesia.

Irham, Muhammad. 2014. Psikologi Pendidikan. Jogjakarta: Ar-Ruzz Media.

Iskandar, M. 2009. Psikologi Pendidikan Sebuah Orientasi Baru. Jakarta: Gaung Persada (GP) Press.

Joyce \& Weil. 1980. Models of Teaching, Second Edition. London: PrenticeHall International.

Muslich, Masnur. 2010. Text Book Writing:

Dasar-dasar Pemahaman,

Penulisan, dan Pemakaian Buku Teks. Jogjakarta: Ar-Ruzz Media.

Nurhadi. 2004. Kurikulum, Pertanyaan, dan Jawaban. Jakarta: PT Gramedia Widia Sarana (Grasindo).

Nurohman, Sabar. 2007. Pendekatan Project Based Learning Sebagai Upaya Internalisasi Scientific Method Bagi Mahasiswa Calon Guru Fisika. (Online), (http://staff.uny.ac.id/sites/default/fil es/132309687/project-based-

learning.pdf), diakses 10 Agustus 2015.

Permendikbud No. 81A Tahun 2013 tentang Implementasi Kurikulum. Kementerian Pendidikan dan Kebudayaan. (Online). (http://www.puskurbuk.net), diakses 30 Maret 2015.

Rusman. 2012. Model-model Pembelajaran: Mengembangkan Profesionalisme Guru. Jakarta. Rajawali Pers.

\section{Sani, Ridwan Abdullah. 2014. Pembelajaran Saintifik untuk Implementasi Kurikulum 2013 (Yayat Sri Hayati, Ed). Jakarta: Bumi Aksara.}

Saptanti, Sari Nur. 2008. Pengembangan Model Pembelajaran Menyimak Fabel dengan Pembelajaran Produktif dan Multimedia Komputer. Tesis tidak diterbitkan: Universitas Negeri Semarang.

Sari, Aina N.F. 2014. Pengembangan Model Pembelajaran Top Rank Matching Questions and Answer Dalam Mata Pelajaran Akuntansi Untuk Siswa Kelas XI IPS SMA Negeri 6 Malang. Skripsi tidak diterbitkan. Malang: Pendidikan Akuntansi Universitas Negeri Malang

Sastrika, dkk. 2013. Pengaruh Model Pembelajaran Berbasis Proyek Terhadap Pemahaman Konsep Kimia dan Keterampilan Berpikir Kritis.eJournal Program Pascasarjana Universitas Pendidikan Ganesha, Volume 3, Online (http://www.undana.ac.id), diakses 10 Agustus 2015.

Sudjana, Nana. 1990. Penilaian Hasil Proses Belajar Mengajar. Bandung: Remaja Rosdakarya.

Sugiyono. 2010. Metode Penelitian Kuantitatif, Kualitatif, dan $R \& D$. Bandung: Alfabeta.

Suyono. 2012. Belajar dan Pembelajaran. Bandung: PT Remaja Rosdakarya.

Trianto. 2010. Mendesain Model Pembelajaran Inovatif-Progresif: Konsep, Landasan, dan Implementasinya pada Kurikulum Tingkat Satuan Pendidikan (KTSP). Jakarta: Kencana.

Trianto. 2012. Model Pembelajaran Terpadu: Konsep, Strategi, dan Implementasinya dalam Kurikulum Tingkat Satuan Pendidikan (KTSP) (Fatna Yustianti, Ed). Jakarta: Bumi Aksara. 
Universitas Negeri Malang. 2010. Pedoman Penulisan Karya Ilmiah

(Edisikelima). Malang: Biro Administrasi Akademik Perencanaan dan Sistem Informasi Bekerja Sama Dengan penerbit Universitas Negeri Malang.

Widoyoko, Eko Putro. 2014. Penilaian Hasil Pembelajaran di Sekolah. Yogyakarta: Pustaka Belajar. 